they are not such as to prevent the permanent and healthy upkeep of the herds when under proper management and control, nor even to prevent the rapid recuperation of their numbers during periods of release from persecution. On the Galapagos every seal that could be found had been killed by 1887 , and the fur trade was surprised when ten years later a vessel came into San Francisco with somewhat above 200 seals from that abandoned rookery. In like manner, the seals on Robben Island were practically exterminated about the time of the Crimean war, when for a year or two 15,000 or 20,000 skins were taken in single voyages, after which the catches dwindled to trifling amounts, and, finally, the place was abandoned, and its existence as a hunting ground all but forgotten; but after fourteen or fifteen years of quiet, the rock was again covered with seals, just as it had been in the old days when first discovered.

Of the present state of the Pribylov herds we have no precise information at hand, but it is at least known that the seals are greatly diminished since the time, some fourteen or fifteen years ago, when they were last visited by British agents; while even then, some years after the arbitration, they were, of course, immensely less than in the palmy days of the fishery. We hope all the more, accordingly, that the agreement which is now said to have been arrived at will in due course be ratified, in the hope and confident belief that in a few years' time this great source of wealth, and this wonderful spectacle of crowded, teeming animal life, will be again as it was in former times. But it remains to be mentioned that the decrease of the Bering Sea herds in recent years is not to be laid at the door of the Canadian sealers, or at least not to nearly so great an extent as of their opposite neighbours, the Japanese. The once large fleet of Canadian sealing schooners has dwindled, we believe, to some four or five, while ever since the Japanese war the Japanese have taken more and more to this pelagic industry. It is said that they were first led so to do when the Russian guards were removed from the Commander Islands during the war, and when accordingly the rookeries lay at the mercy of the first comer. In recent years they have been charged with actually raiding the American rookeries. and, in any case, as Japan was no party to the Bering Sea Treaty, the Japanese captains have up to the present been free to use firearms, and to pursue their trade up to the three-mile limit of the territorial waters. In 1908, the Japanese had a fleet of thirty schooners, some with as many as sixteen boats, which formed a cordon round the Pribylov Islands. There can be no doubt at all that this has told very heavily upon the herds. Lastly, it is right to say that the terms of the new agreement, and the compensation which it is proposed to pay to Canada and Japan for the loss of their pelagic interests, appear to be both liberal and enlightened, and indicate a sincere desire on the part of the United States and of Russia to do all that lies in their power for the attainment of a great national and general benefit, and for the preservation of one of the great phenomena of the living world.

D. W. T.

\section{THE EDUCATION AND TRAINING OF} ENGINEERS.

THE Conference on the Education and Training of Engineers, held at the Institution of Civi] Engineers, at the end of June, of which a report appeared in our issue of last week, marks a further advance in the development of a scheme which has engaged the attention of the council during the last NO. 2 I76, VOL. 87$]$ fifteen years, and cannot fail to have considerable influence on the future of the engineering profession. The first step was taken under the presidency of Sir John Wolfe Barry, when a system of qualifying examinations was established. Candidates who were desirous of entering the institution as students had to give proof of a sound general education developed upon lines suited to subsequent scientific study. Every candidate for associate membership was required to give proof of a competent knowledge of those branches of science which form the basis of engineering, and to have received an adequate practical training under actual engineering conditions. The council found it necessary, from the first, to organise special examinations; these are still continued, and largely availed of by candidates for admission in both the classes mentioned. On the other hand, the council was desirous of minimising the number of examinations to which candidates were subjected, and was prepared to recognise degrees or diplomas granted by universities, university colleges, and engineering colleges, but only on condition that the standard of attainment represented by these degrees and diplomas was not inferior to that imposed by the council's own examinations.

Subsequent experience has shown that the advantages which were anticipated at the outset have been more than fulfilled. The imposition of more stringent conditions put a temporary check upon the numbers of those who entered the institution, particularly in the student class, but this check was only of short duration, and the rate of admission speedily began to grow. It may now be confidently asserted that every associate member admitted to the institution has satisfied the council that he does possess a competent knowledge of both the science and practice of his profession. In fact, British civil engineering, through the action described, has fully established its claim to rank as a learned profession, while the stringency and standard of the conditions which must be fulfilled by all successful candidates are certainly in no respect inferior to those imposed by the medical and legal professions. Another important advantage resulting from the action of the council has been the establishment, throughout the British Empire, of a practically uniform standard of attainment for engineering graduates of universities and university colleges. This excellent result has come about chiefly because the authorities of these institutions have appreciated fully the advantages attaching to the recognition of their degrees by the council of the Institution of Civil Engineers as a substitute for success in examinations held by the institution itself; and, as before stated, the policy of the council has always been to minimise examinations so far as may be possible.

On the side of practical training the council has never delegated, and probably never will delegate, to any other body the duty of deciding whether or not the training of individual candidates is satisfactory. Not merely does the council insist on the production by candidates of articles, indentures, or certificates given by trustworthy persons who have personal knowledge of the training which each candidate has undergone, but it has instituted special and stringent forms in which the details of that practical training must be recorded, and these statements have to be supplemented and verified by the testimony of members of the institution who have personal knowledge of each candidate's career and work. In other words, while recognising the value of scientific education for engineers, the claims of practical training are in no way subordinated thereto: both are essential.

In roo3 the council decided to invite the cooperation 
of the leading engineering institutions in the United Kingdom in setting up a special committee which should consider and report to the council on the broad principles of engineering education and training likely to yield the best results. Sir William White, who was then president of the institution, was appointed chairman of the committee; its membership embraced a considerable number of men occupying eminent positions in the practice of all branches of engineering. The inquiries of the committee included general preparatory education, as well as the scientific and practical training of those who were proposing to enter the engineering profession. The work to be done, therefore, was very extensive in its range, and occupied the committee more than two years. The report was unanimous, and was approved by the council of the Institution of Civil Engineers and by the councils of the other engineering institutions which had been represented on the committee. That report has exercised great influence since its appearance, and as the council of the institution arranged for its publication at a low price (by Messrs. Clowes and Sons) it has obtained a wide circulation, both at home and abroad. One of the most valuable features in this report was an appendix containing the analysis of replies made by a large number of eminent practising civil engineers to a series of questions framed and circulated by the committee. From this analysis it became evident that the suggestions made in the report not merely represented the views of the members of the committee, but that the recommendations of the committee were endorsed by the great majority of engineers consulted. In the main the report undoubtedly represented, and still represents, the views of the leading men in the civil engineering profession. Five years have passed since the report was issued, and the council of the institution this year reached the conclusion that many questions of detail and of method which were involved in the realisation of the principles laid down in the report might with advantage receive further consideration. It was mainly for the purpose of affording an opportunity of discussing important questions of that kind that the recent conference was held.

The broad conclusions of the members of the conference in regard to preparatory education of boys who may be intended to become engineers were confirmatory of opinions expressed in the education committee's report of 1906: a gond general education, including modern languages, was considered to be essential, and early specialisation was deprecated. The advantages obtained by engineering students who are attached to a university were generally admitted, but one most interesting feature of the discussions was an outspoken declaration by professors of engineering in favour of the practical workshop training being chiefly obtained in manufacturing establishments rather than in college workshops. As to practical training, anyone who has studied the subject cannot fail to have been impressed with the enormous importance attaching to friendly relations between engineering employers and college students.

The question of the period at which practical training should be undertaken by those who intended to receive a college training has been much discussed. The report of the education committee of 1906 recommended that boys after leaving a secondary school (say, at the age of seventeen or eighteen) should serve for about a year in mechanical engineering workshops, so as to gain some knowledge of practical conditions and work. It was also recommended that at the age of about nineteen they should proceed to college and complete their scientific training, taking courses of three or four years, and availing themselves of any opportunities for practical training durNO. 2 I 76 , VOL. 877 ing the vacations. After graduation, their practical training in such branches of engineering as they might desire to follow would be completed. This clear statement of the committee's report was not grasped by some of the. speakers at the recent conference, some of whom argued that the whole of the practical training should be taken between the secondary school and the college, while others maintained that all the practical training should be taken after the college course was completed, in order that there should be no break between the secondary school and the college. The balance of opinion, however, was much in favour of the committee's suggestion, and that also represents the established practice in Germany. Formerly all practical training in that country was put after the technical university or high-school education; but experience led the Germans to adopt the system which the education committee recommended. After twelve years' trial of the new arrangement, the German authorities are more than ever in favour of its beneficial effects.

No doubt whatever was expressed as to the absolute necessity of thorough scientific training for all engineers. There was equally universal acceptance of the view that no man can be considered fit to take part in the design, as well as in the control and direction, of engineering works, unless there is added to a competent scientific knowledge a thorough practical training under actual engineering conditions.

In announcing their decision to summon the conference, the council expressed the hope that it would be widely supported by those interested in solving the difficulties and uncertainties which are experienced by aspirants to membership of the engineering profession. The result of the conference has shown that this hope was well founded. No one who took part in the conference will entertain the least doubt as to the value and interest of its proceedings or of the certain and considerable benefits which will result therefrom to the engineering profession.

W. H. W.

\section{THE PROBLEM OF PITHECANTHROPUS. ${ }^{1}$}

NEARLY twenty years have gone since Eugene Dubois, then a young surgeon attached to the Dutch forces in Java, and now professor of geology in the University of Amsterdam, discovered that remarkable individual to which he gave the name of Pithecanthropus erectus. The actual discovery, it will be remembered, consisted of the roof of a skull, a thigh bone, and two teeth; they were found in a fossilbearing stratum on the left bank of the Solo or Bengawan, a stream which, after flowing through the province of Mediun-"the hell of Java "-in the centre of the island, turns in a north-easterly direction to reach the sea. Experts agree that the bones found were parts of the same individual or at least of individuals of the same race or species. As to the nature of the individual, there has been a wide divergence of opinion; the discoverer regarded it as more anthropoid than human, hence the name, while others, looking on it as altogether human, simply name it the "fossil man of Java."

The position of Pithecanthropus amongst the higher primates is still debated; while one school of experts places it in the direct line of human evolution, another regards it as part of a side stem which ended in extinction. The age of the formation in which it was found is also still under discussion; Dubois assigned the fossil-bearing layer to late in the Pliocene period;

1 "Die Pithecanthropus-Schichten auf Java." Geologische und Paläonto logische Ergebnisse der TrinilExpedition (ro07-1908). Herausgegeben von logische Ergebnisse der TrinilExpedition (r907-1908). Herausgegeb (Leipzig: W. Engelmann, rgr I.) Price 5o marks. 